\title{
Numerical Simulation OF AEROELASTIC EFFECTS FOR AN AirfoIL WITH TwO DEGREES OF FREEDOM
}

\author{
Marek Pátý ${ }^{1}$; Jan Halama \\ Czech Technical University in Prague, Faculty of Mechanical Engineering, \\ Department of Technical Mathematics, Center of Advanced Aerospace Technology, \\ Technická Street 4, Prague 6, 166 07, Czech Republic \\ e-mail: ${ }^{1}$ marek.paty@fs.cvut.cz
}

\begin{abstract}
The pursuit of increased steam turbine power output leads to a design of low pressure stages with large diameters, featuring long and thin blades. The interaction of the structure with flow may induce vibrations, leading to a reduced operational life of the machine due to material fatigue. This work introduces a mathematical model of fluid-structure interaction, intended for the investigation of flow-induced turbine blade vibrations. At present, it is applied to a simplified test case of an isolated airfoil. The flow model is based on 2D Euler equations in Arbitrary Lagrangian-Eulerian formulation, discretized by the Finite Volume Method with a second-order accurate $\mathrm{AUSM}^{+}$-up scheme. The structure is modelled as a solid body with one rotational and one translational degree of freedom. The solution is realized iteratively by a time-marching method with a two-way fluid-structure coupling. In each iteration the airfoil surface pressure is integrated to determine the forces and the torsional moment driving its motion. The position of the airfoil in the next time step is obtained and the flow is resolved on a newly recreated mesh. The results of the present model are validated by comparison with experimental data and with numerical results of other models.
\end{abstract}

\section{Keywords}

Aeroelasticity; Turbine; Airfoil; Vibrations; Arbitrary Lagrange-Euler; Finite volume method.

\section{Introduction}

The phenomenon of aeroelasticity was first investigated in the field of aeronautics. Collar [1] states that the subjects of structure dynamics and aerodynamics cannot be treated separately and they have to be regarded as components of an integral analysis. He defines aeroelasticity as a discipline studying the combined effects of aerodynamic, elastic and inertial forces. Its role has since been recognized as crucial in a variety of other disciplines, such as civil engineering, biomedicine [2] and turbomachinery ([3], [4]).

The most widely investigated dynamic aeroelastic effect in aeronautics is flutter (see e.g. the works [5], [6], [7]), which is also of interest in turbomachinery [8], together with forced response analysis [9]. Flutter is a self-excited vibration of structure, caused by the interaction of aerodynamic, elastic and inertial forces. The structure aerodynamic loading leads to a deformation of the body, which in turn increases the aerodynamic forces. The wing or blade thus vibrates with amplitude of oscillations increasing in each cycle, leading to a mechanical failure. While no loss of turbine blade due to flutter is known ([4]), it has been reported to cause cracking of the blade root [10].

The problem of flutter requires considering non-linear behaviour of both flow and elastic structure, change of domain and mesh in time, flow viscosity and turbulence effects [7]. Efforts have been made in the past to simplify the problem and to restrict the model to include 
only the most essential effects. The first attempts to solve the flutter problem analytically can be traced back to the works of Theodorsen [11], of interest is also the recent examination of the model by Perry [12], who introduced a model for aeroelastic flutter behaviour of an airfoil with aileron using simplifying assumptions such as potential flow and zero thickness of the wing.

The advance of Computational Fluid Dynamics (CFD) and the rise in computational power allowed treating the aeroelasticity problems with numerical approaches. In order to keep the computational demands reasonable, flutter was first modelled by superimposing linear perturbations to a steady-state nonlinear solution and casting the equations to frequency domain. However, the assumption that the steady-state flow is identical with the time-mean flow may not always be valid and linear methods are incapable of capturing important nonlinear effects such as large amplitudes of blade motion or strong unsteady shocks ([13], [6]). The shortcomings of the harmonic time-linearized method are addressed by the non-linear harmonics (NLH) method introduced by Ning and He [14]. The time-mean equations are solved simultaneously with the harmonic perturbations and coupled via extra unsteady stress terms appearing due to the time-averaging. Ning and $\mathrm{He}$ demonstrate on a transonic compressor cascade that the NLH method captures successfully the nonlinear effects and achieves results close to a time-marching method.

The inherent drawback of the NLH method is that the unsteadiness is resolved only in a limited number of harmonics whose frequency is not a part of the solution and it has to be given as an input at the start of the procedure. The full unsteady solution of fluid-structure interaction can be obtained by time-marching methods. Traditionally, the structural mechanics problems are modelled using Lagrangian description, while the fluid dynamics problems usually employ Eulerian description [15]. The moving fluid-domain boundaries in fluidstructure interaction problems can be conveniently treated by a hybrid Arbitrary LagrangianEulerian (ALE) description, allowing a deformation of the physical domain independent of the fluid particle motion (see e.g. [15], [16], [17]). The stability and accuracy of the numerical methods in ALE formulation is closely related to the Geometric Conservation Laws (GCL) which require that a constant solution is reproduced exactly. An elaborate analysis of several time-advancing schemes in view of GCL is given in [17]. The deformation of the domain implies that the grid for the ALE formulation needs to be updated accordingly, posing a third problem additionally to the fluid and structure dynamics [15]. A brief summary of grid movement techniques is provided in [6], while a complete remeshing may be required for large domain deformations [18].

As the solution of the complete fluid-structure interaction is very complex, it is often simplified by imposing only a one-way coupling between the fluid and structure dynamics. The eigenmodes and eigenfrequencies are determined in advance by a structural solver and used to prescribe the structure motion for an unsteady fluid dynamics solver ([19], [20]). The unsteady aerodynamic load on the structure surface is extracted to compute the energy transferred from the fluid to the structure and by comparison with the structural damping to evaluate the susceptibility to flutter. The underlying assumption that the effect of aerodynamic forces on the change of the structural dynamics properties can be neglected requires that the fluid density is by several orders of magnitude lower than that of the solid. This makes the method suited for turbomachinery or aeronautics, while it is inapplicable e.g. for computational medicine where the fluid and solid densities are similar [2]. However, evidence suggests that this approach may fail even in cases with significant density difference [21] and a strong fluid-structure coupling should therefore be always included.

The efforts to avoid modelling of the complete fluid-structure interaction root mainly from the incompatibility of the approaches traditionally used to treat isolated structure and fluid 
dynamics problems. Typically, CFD has been solved with Finite Volume Methods (FVM) and computational structural mechanics (CSM) with Finite Element Methods (FEM), differing often in solution and discretization techniques [22]. This poses difficulty in transferring data across the fluid-structure domain interface, where the aerodynamic surface load imposes a boundary condition for structure dynamics and the displacement of the solid body deforms the fluid computational domain. A number of works has been published on solving the structure and fluid dynamics equations in a compatible fashion, some using the same discretization methods for both domains and the others a combination of different ones: Slone et al. [23] employed a single Finite Volume Unstructured Mesh discretization strategy for both fluid and structure, Sváček [7] and Honzátko [24] computed flow around a solid airfoil with two degrees of freedom using FVM- and FEM-based incompressible flow solvers respectively, Sanches and Coda [15] discretized flow equations with FEM and modelled the structure with FEM shell elements.

In the present paper, we examine the onset of flutter for a NACA 0012 airfoil modelled as a solid body with two degrees of freedom, allowing a translational and a rotational movement. The flow around the airfoil is modelled using Euler equations in ALE formulation, discretized by the FVM. A time-marching iterative procedure is employed, solving simultaneously the unsteady flow and airfoil movement with strong coupling realized via the airfoil aerodynamic loads and displacement. As the final intended application of the model is to solve flutter in turbomachinery, the employed numerical scheme for approximation of inviscid fluxes needs to be capable of resolving compressible flows accurately and of capturing shock-waves sharply. A modern flux splitting scheme AUSM+-UP was employed, introduced originally by Liou and Steffen [25] as AUSM and modified for the low-speed flow regimes by Liou [26].

\section{$1 \quad$ Mathematical Model}

This chapter describes the mathematical model of fluid flow around an oscillating airfoil. First, the Euler equations describing the inviscid compressible flow are introduced in ALE formulation, including the definition of boundary conditions. Then the motion of the airfoil as a solid body with one translational and one rotational degree of freedom is defined together with the coupling to the aerodynamic field.

\subsection{Flow Model}

We denote $\Omega_{t}$ the computational domain occupied by fluid at time $t \in\langle 0, T\rangle$. We aim to find the fluid density $\rho$, velocity $u=u(x, t)$ and static pressure $p$ for $t \in \Omega_{t}$, where $u=\left[u_{1}, u_{2}\right]^{T}$ has two components $\mathrm{u}_{1}, \mathrm{u}_{2}$ in the directions of Cartesian axes $x_{1}, x_{2}$. Further we denote the total energy $e_{t} \frac{1}{2}\left(u_{1}^{2}+u_{2}^{2}\right)$, using the notation $e$ for internal energy.

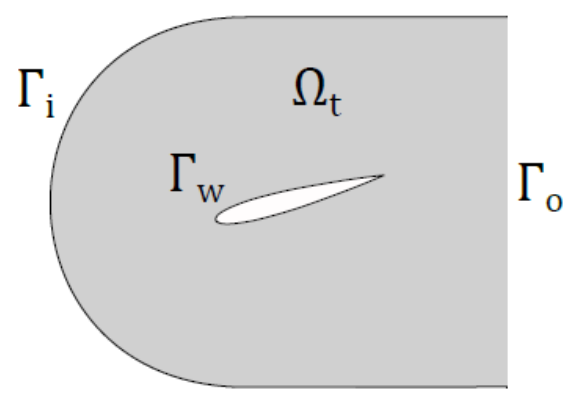

Fig. 1: Domain and boundaries (not in scale). 
We consider the domain at time $t=0$ as the reference domain $\Omega_{r e f}=\Omega_{0}$ and introduce the ALE mapping [7]:

$$
A_{t}: \Omega_{r e f} \rightarrow \Omega_{t}, X \rightarrow x(X, t)=A_{t}(X),
$$

describing the time-dependent position $x \in \Omega_{t}$ of a point from reference domain $X \in \Omega_{\text {ref }}$. The ALE velocity is defined as: $s=\partial A_{t} / \partial t$. We consider the set of Euler equations [27]:

$$
\frac{\partial}{\partial t} \int_{\Omega_{t}} \boldsymbol{W} d \Omega+\oint_{\Gamma(t)} \boldsymbol{F}(\boldsymbol{W}, \boldsymbol{n}, \boldsymbol{s}) d \Gamma=0,
$$

where $n=\left[n_{1}, n_{2}\right]^{\mathrm{T}}$ is the surface outward unit normal. The vector of characteristic variables $\mathbf{W}$, and the flux vector $\mathbf{F}$ are defined as:

$$
\boldsymbol{W}=\left[\begin{array}{c}
\rho \\
\rho \boldsymbol{u} \\
\rho e_{t}
\end{array}\right], \boldsymbol{F}=(\boldsymbol{u}-\boldsymbol{s}) \cdot \boldsymbol{n} \boldsymbol{W}-\left[\begin{array}{c}
0 \\
-p \boldsymbol{n} \\
-p \boldsymbol{s} \cdot \boldsymbol{n}
\end{array}\right]
$$

The system of equations is closed by the ideal gas law:

$$
p=(\gamma-1)\left[\rho e_{t}-\rho \frac{u_{1}^{2}+u_{2}^{2}}{2}\right]
$$

We consider three types of boundary conditions: at the airfoil wall $\Gamma_{w}$, at the domain inlet $\Gamma_{i}$ and outlet $\Gamma_{o}$ (Fig. 1). The free-slip boundary condition is applied at the airfoil wall by imposing the normal component of flow velocity equal to the normal component of wall movement velocity (Eq. 5). Freestream conditions are prescribed at the domain inlet (Eq. 6) and constant solution in the direction of boundary normal is defined at the outlet (Eq. 7).

$$
\begin{gathered}
{[(\boldsymbol{u}-\boldsymbol{s}) \cdot \boldsymbol{n}]_{\Gamma_{w}}=0} \\
\left.\boldsymbol{u}\right|_{\Gamma_{i}}=\boldsymbol{u}_{F S},\left.\rho\right|_{\Gamma_{i}}=\rho_{F S},\left.p\right|_{\Gamma_{i}}=p_{F S} \\
\left.\frac{\partial \boldsymbol{u}}{\partial \boldsymbol{n}}\right|_{\Gamma_{o}}=\mathbf{0},\left.\frac{\partial \rho}{\partial \boldsymbol{n}}\right|_{\Gamma_{o}}=0,\left.\frac{\partial p}{\partial \boldsymbol{n}}\right|_{\Gamma_{o}}=0
\end{gathered}
$$

The initial condition for a steady-state computation is described by freestream conditions:

$$
[\rho, \boldsymbol{u}, p](\boldsymbol{x}, 0)=\left[\rho_{F S}, \boldsymbol{u}_{F S}, p_{F S}\right], \boldsymbol{x} \in \Omega_{0}
$$

The unsteady computations are performed by solving the steady-state case first and using the solution as initial condition. 


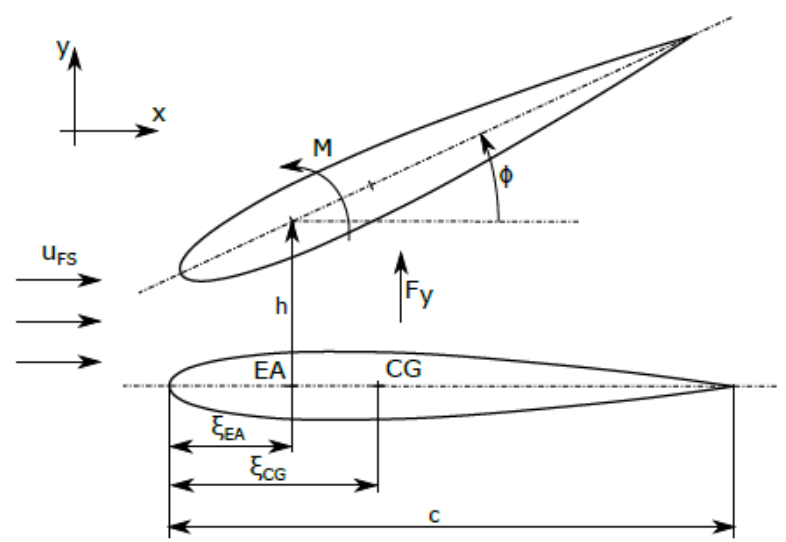

Fig. 2: Airfoil parameters and position.

\subsection{Airfoil Motion}

The airfoil is modelled as a solid body with two degrees of freedom, allowing movement in a vertical direction and a rotation about elastic axis (EA). The equations describing the airfoil motion can be derived from Lagrange equations (see e.g. [7]). We consider the nonlinear form:

$$
\begin{gathered}
m \ddot{h}+k_{h h} h+S_{\phi} \ddot{\phi} \cos \phi-S_{\phi} \phi^{2} \sin \phi+b_{h h} \dot{h}=F_{y}, \\
S_{\phi} \ddot{h} \cos \phi+I_{\phi} \ddot{\phi}+k_{\phi \phi} \phi+b_{\phi \phi} \dot{\phi}=M
\end{gathered}
$$

and the linearized form, valid for small vibration amplitudes of the angle $\phi$ and its derivative $\dot{\phi}$ :

$$
\begin{gathered}
m \ddot{h}+k_{h h} h+S_{\phi} \ddot{\phi}+b_{h h} \dot{h}=F_{y}, \\
S_{\phi} \ddot{h}+I_{\phi} \ddot{\phi}+k_{\phi \phi} \phi+b_{\phi \phi} \dot{\phi}=M,
\end{gathered}
$$

where $h$ is the airfoil vertical displacement (positive in upwards direction), $\phi$ is the airfoil rotation angle (positive in counter-clockwise direction), $m$ its mass, $S_{\phi}$ the static moment about EA and $I_{\phi}$ the moment of inertia about EA (Fig. 2). The elastic support of the airfoil has stiffness $k_{h h}$ in vertical and $k_{\phi \phi}$ in rotational direction with the respective mechanical damping denoted as $b_{h h}$ and $b_{\phi \phi}$. The aerodynamic load acting on the airfoil, i.e. the lifting force $F_{y}$ (positive in upwards direction) and the torque $M$ (positive in counter-clockwise direction), is calculated by integrating the airfoil pressure distribution obtained from the flow solver:

$$
\boldsymbol{F}=\left[\begin{array}{l}
F_{x} \\
F_{y}
\end{array}\right]=\oint_{\Gamma_{w}}-p \boldsymbol{n} d \Gamma, M=\oint_{\Gamma_{w}}\left[\begin{array}{l}
x_{E A}-x \\
y-y_{E A}
\end{array}\right] \cdot \boldsymbol{n} p d \Gamma
$$

\section{$2 \quad$ Numerical Solution}

\subsection{Grid}

The computational domain surrounding the NACA 0012 airfoil extends 9 chord lengths upstream, 4 chord lengths downstream and 10 chord lengths up and down vertically of the airfoil leading edge (LE). Two structured C-type grids with different level of refinement were 
generated for the numerical solution. The fine grid features $516 \times 49$ cells, while the coarse one contains 256x24 cells (Fig. 3). The movement of the airfoil in unsteady computations requires that the mesh is updated accordingly. We consider two configurations: the reference configuration where the airfoil angle and displacement are equal to zero, and another configuration where the whole mesh is displaced and rotated as a rigid body with the airfoil.
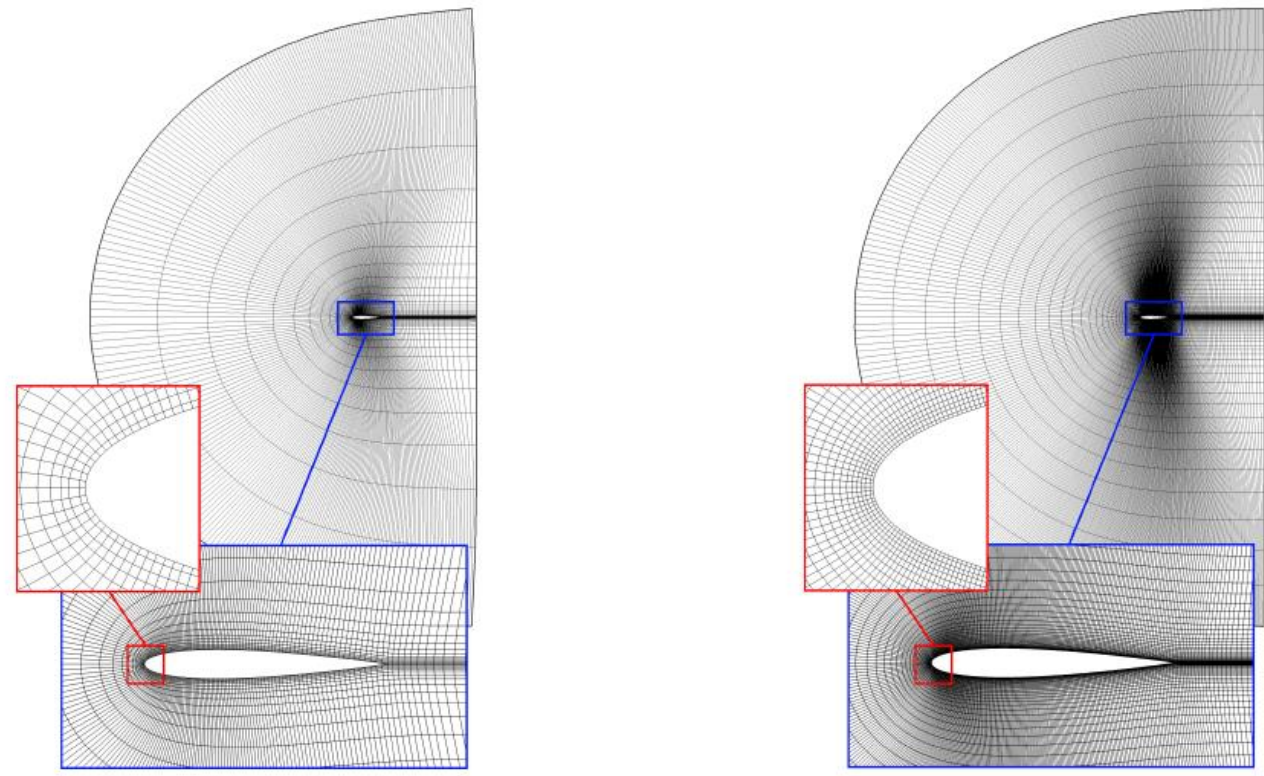

Fig. 3: Coarse (left) and fine grid (right).

The instantaneous position of each grid point is a result of linear combination of these two configurations:

$$
\left[\begin{array}{l}
x \\
y
\end{array}\right]=k\left[\left(\begin{array}{c}
x_{r e f}^{E A} \\
y_{r e f}^{E A}+h
\end{array}\right)+\boldsymbol{Q}\left(\begin{array}{c}
x_{r e f}-x_{r e f}^{E A} \\
y_{r e f}-y_{r e f}^{E A}
\end{array}\right)\right]+(1-k)\left[\begin{array}{l}
x_{r e f} \\
y_{r e f}
\end{array}\right],
$$

where $h$ is the displacement of the airfoil elastic axis and the rotation matrix $\boldsymbol{Q}$ is defined using the airfoil rotation angle $\phi$ :

$$
\boldsymbol{Q}=\left[\begin{array}{cc}
\cos \phi & -\sin \phi \\
\sin \phi & \cos \phi
\end{array}\right]
$$

The coefficient $k$ is a linear function of the point distance from the nearest airfoil point $d_{\text {min }}$, such that the grid points forming the airfoil boundary are fully displaced and the grid points further than a distance limit $d_{\text {lim }}$ stay at their reference configuration position:

$$
k=\max \left(1-d_{\text {min }} / d_{\text {lim }}, 0\right)
$$

\subsection{Spatial Discretization of Euler Equations}

The Finite Volume Method (FVM) is used for the discretization of Euler equations in ALE formulation. Let us divide the computational domain $\Omega$ into a set of $N$ non-overlapping subsets (cells) $\Omega_{i}$ such that

$$
\Omega=\bigcup_{i=1}^{N} \Omega_{i}, \quad \Omega_{i} \cap \Omega_{j}=\emptyset, \quad \forall i \neq j
$$


The integral conservation law Eq. 2 has to be satisfied in each finite volume cell $\Omega_{i}$. We consider the integral boundary flux of the polygonial cell as a sum of fluxes through its walls, where $\Gamma_{i j}$ stands for the edge between the cell $i$ and a neighbouring cell $j$ and the average flux along the edge is denoted by $\overline{\boldsymbol{F}}_{i j}$ :

$$
\oint_{\Gamma_{i}} \boldsymbol{F}(\boldsymbol{W}, \boldsymbol{n}, \boldsymbol{s}) d \Gamma=\sum_{j \in N_{i}} \overline{\boldsymbol{F}}_{i j}|| \Gamma_{i j}||
$$

The numerical approximation $\widetilde{\boldsymbol{F}}_{i j}$ of the flux $\overline{\boldsymbol{F}}_{i j}$ was obtained by the AUSM-family scheme in the first (AUSM+, [28]) and second modification (AUSM+-up, [26]) by Liou. The idea of the AUSM schemes is to split the flux into the convective and pressure part and to treat them separately:

$$
\widetilde{F}_{1 / 2}=\widetilde{F}_{1 / 2}^{c}+\widetilde{F}_{1 / 2}^{p}
$$

where the $1 / 2$ subscript indicates evaluation at cell interface.

The definition of the convective and pressure terms for M-split AUSM+ scheme in ALE formulation can be found in [29]:

$$
\widetilde{\boldsymbol{F}}_{\mathbf{1} / \mathbf{2}}^{\boldsymbol{c}}=M_{1 / 2}^{r} a_{L / R}\left[\begin{array}{c}
\rho \\
\rho \boldsymbol{u} \\
\rho e_{t}+p
\end{array}\right]_{L / R}, \widetilde{\boldsymbol{F}}_{\mathbf{1} / \mathbf{2}}^{\boldsymbol{p}}=\left[\begin{array}{c}
0 \\
p \boldsymbol{n} \\
p \boldsymbol{s} \cdot \boldsymbol{n}
\end{array}\right]_{1 / 2}
$$

where $a$ is the speed of sound and the ${ }_{\mathrm{L} / \mathrm{R}}$ subscript indicates that the expression is evaluated in either one or the other of the interface-adjacent cells, based on the upwinding principle. The notable differences of the ALE formulation in comparison to the Eulerian reference frame arise in the use of the relative Mach number $M^{r}=(u-s) \cdot \boldsymbol{n} / a$ instead of an absolute one and in the appearance of the new $p s \cdot n$ term in the pressure part of flux. Formulas for the evaluation of the interface quantities $M_{1 / 2}^{r}, p_{1 / 2}$ are introduced in [25].

The need for a universally applicable and robust numerical scheme lead to an extension of the AUSM scheme to low-speed flows with the introduction of the $\mathrm{AUSM}^{+}$-up modification in [26]. The newly constructed scheme is applicable to all speed regimes and removes the deficiency of the previous versions, which suffers from pressure oscillations along the grid direction with a very small velocity component, such as in the direction normal to the boundary layer. The formulation of the convective flux uses mass-flow splitting instead of Mach number splitting, here given already in the ALE formulation using the flow velocity relative to the interface to evaluate the mass-flow $\mathrm{m}^{r}$ :

$$
\widetilde{\boldsymbol{F}}_{\mathbf{1} / \mathbf{2}}^{\boldsymbol{c}}=\dot{m}_{1 / 2}^{r}\left[\begin{array}{c}
1 \\
\boldsymbol{u} \\
e_{t}+p / \rho
\end{array}\right]_{L / R}
$$

The extra term $p s \cdot n$ appears again in the pressure flux due to the ALE configuration. The reader is referred to Liou's paper [26] for the evaluation of the interface quantities. The coefficients of the scheme were set as in the example given by Liou to $K_{u}=0.75, K_{p}=0.25$ and $\sigma=1.0$.

In order to increase the accuracy of the scheme, the quantities at the left and right side of the interface are obtained by using a linear reconstruction with TVD-based limiting of slopes [30]. In particular the min-mod limiter was employed in order to enhance the scheme stability. 


\subsection{Time Integration and GCL}

We substitute the numerical approximation of cell fluxes (Eq.16) into the set of Euler equations (Eq. 2) and by denoting the space-averaged state vector as $\overline{\boldsymbol{W}}$ we obtain the following semidiscrete form:

$$
\frac{d}{d t}(\overline{\boldsymbol{W}} \Omega)_{i}+\boldsymbol{R}_{i}=0, \boldsymbol{R}_{i}=\sum_{j \in N_{i}} \overline{\boldsymbol{F}}_{i j}\left\|\Gamma_{i j}\right\|,
$$

where $\mathbf{R}$ is the residual vector.

We use the explicit Euler scheme and the second-order accurate 4-stage Runge-Kutta scheme (RK4) to integrate the system in time. While both schemes are a routinely used technique for numerical integration, a special attention has to be paid to meeting the GCL condition for ALE formulation. The Euler scheme is defined as:

$$
\boldsymbol{W}^{n+1}=\frac{1}{\Omega^{n+1}}\left[\boldsymbol{W}^{n} \Omega^{n}-\Delta t \boldsymbol{R}\left(\boldsymbol{x}^{n+1 / 2}, \boldsymbol{s}^{n+1 / 2}, \boldsymbol{W}^{n}\right)\right]
$$

The GCL requires that the residual vector is evaluated on a mid-point grid in between the two time steps $n$ and $n+1$ [27]:

$$
\boldsymbol{x}^{n+1 / 2}=\frac{\boldsymbol{x}^{n}+\boldsymbol{x}^{n+1}}{2}, \boldsymbol{s}^{n+1 / 2}=\frac{\boldsymbol{x}^{n+1}-\boldsymbol{x}^{n}}{\Delta t}
$$

To obtain the mid-point grid, we first need to determine the position of the grid in the next time-step, denoted as $\boldsymbol{x}^{n+1}$. We transform the set of the two second-order ordinary differential equations (ODEs) describing the airfoil motion (Eq. 9 or 10) into a set of four first order ODEs:

$$
\dot{\boldsymbol{q}}=f(\boldsymbol{q}), \boldsymbol{q}=[h, \dot{h}, \boldsymbol{\phi}, \dot{\phi}]
$$

We integrate the equation numerically in time and obtain a new airfoil position:

$$
\boldsymbol{q}^{n+1}=\boldsymbol{q}^{n}+\Delta t f\left(\boldsymbol{q}^{n}\right)
$$

Now we can employ the technique described in Section 3.1 to update the whole mesh with the new airfoil position.

The RK4 scheme is expressed as:

$$
\begin{gathered}
\boldsymbol{W}^{(0)}=\boldsymbol{W}^{n}, \\
\boldsymbol{W}^{(k)}=\frac{1}{\Omega^{(k)}}\left[\boldsymbol{W}^{n} \Omega^{n}-\alpha_{k} \Delta t \boldsymbol{R}\left(\boldsymbol{x}^{\left(k-\frac{1}{2}\right)}, \boldsymbol{s}^{\left(k-\frac{1}{2}\right)}, \boldsymbol{W}^{(k-1)}\right)\right], \\
k=1, \ldots, 4, \\
\boldsymbol{W}^{n+1}=\boldsymbol{W}^{(4)},
\end{gathered}
$$

with the coefficients set to $\alpha_{1}=1 / 4, \alpha_{2}=1 / 3, \alpha_{3}=1 / 2$ and $\alpha_{4}=1$.

Again a mid-point grid is used to uphold the GCL, analogically to the Euler scheme:

$$
\boldsymbol{x}^{(k-1 / 2)}=\frac{\boldsymbol{x}^{n}+\boldsymbol{x}^{(k)}}{2}, \boldsymbol{s}^{(k-1 / 2)}=\frac{\boldsymbol{x}^{(k)}-\boldsymbol{x}^{n}}{\alpha_{k} \Delta t}
$$


The RK4 scheme for the temporal integration of the first order ODEs describing the airfoil motion (Eq. 23) is defined as

$$
\boldsymbol{q}^{(k)}=\boldsymbol{q}^{n}+\alpha_{k} \Delta t f\left(\boldsymbol{q}^{(k-1)}\right)
$$
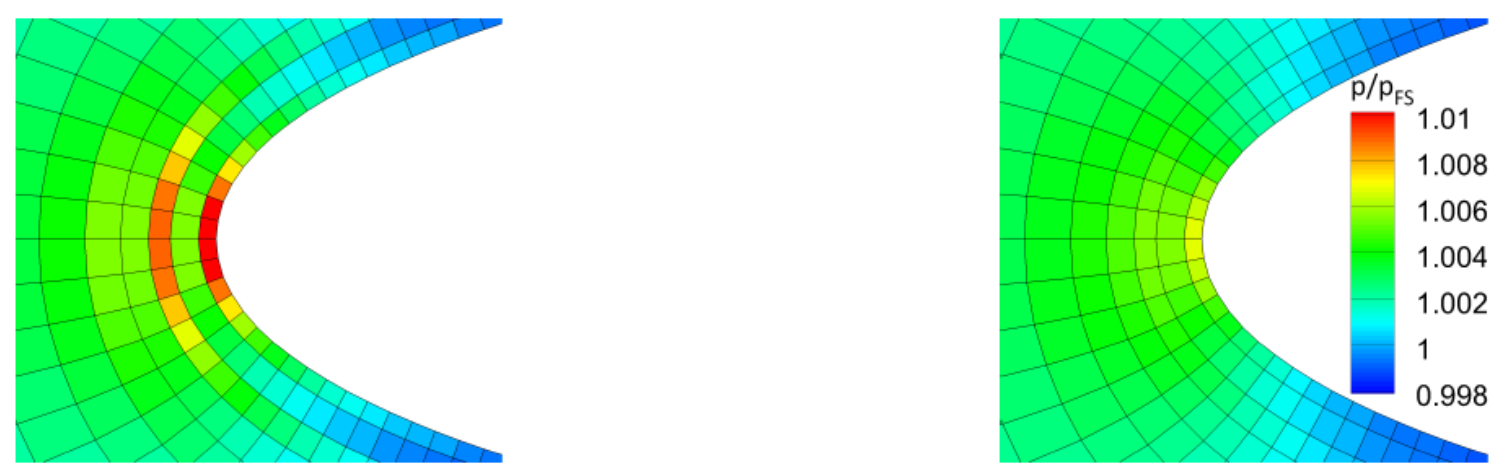

Fig. 4: Distribution of non-dimensional pressure near airfoil LE from AUSM+ (left) and AUSM+-up scheme (right) for $u_{1, F S}=30 \mathrm{~m} / \mathrm{s}$.

\section{$3 \quad$ Results and Discussion}

\subsection{Steady-State Solution}

Steady state computations were performed to validate the numerical flow model by comparison with experimental data. The airfoil is fixed in position with $h=0 \mathrm{~m}$ and $\phi=0^{\circ}$ and the flow is iteratively computed by the time-marching method until it converges to a timeconstant solution. The airfoil chord length is $\mathrm{c}=0: 3 \mathrm{~m}$ and the inlet boundary conditions are defined by the free-stream flow quantities $\rho_{F S}=1.225 \frac{\mathrm{kg}}{\mathrm{m}^{3}}, u_{F S}=[30,0]^{T} \frac{\mathrm{m}}{\mathrm{s}}, p_{F S}=$ $101325 \mathrm{~Pa}$

Figure 4 shows the distribution of static pressure near the airfoil leading edge, normalized by the free-stream static pressure $p_{F S}$. The solutions obtained by the $\mathrm{AUSM}^{+}$and AUSM+-up schemes are compared. As noted by Liou [26], the original $\mathrm{AUSM}^{+}$scheme suffers from oscillations appearing along the grid direction with small velocity component, which are here observed in the direction normal to the airfoil surface. The pressure oscillations influence directly the airfoil pressure distribution and lead to an inaccurate computation of the airfoil aerodynamic load, yielding the $\mathrm{AUSM}^{+}$scheme unusable for the present model. The modified $\mathrm{AUSM}^{+}$-up performs satisfactorily, as it produces a smoother static pressure distribution virtually free of spurious oscillations. The rate of convergence is demonstrated in Fig. 5 by means of density residuals. While the $\mathrm{AUSM}^{+}$scheme stops converging after 70000 iterations, the $\mathrm{AUSM}^{+}$-up scheme shows a steady convergence with residuals still diminishing after having dropped by 6 orders of magnitude. Note that the second order reconstruction is not employed in either of the cases, as it caused the $\mathrm{AUSM}^{+}$scheme to diverge. All other computations performed in this paper employ the $\mathrm{AUSM}^{+}$-up scheme with reconstruction.

The comparison of computations performed on two grids with different level of refinement is shown in Fig. 6. The isolines of pressure $c_{p}$ are plotted, employing the definition

$$
c_{p}=\frac{p-p_{F S}}{\frac{1}{2} \rho_{F S} u_{r e f}^{2}}
$$


where the reference velocity $u_{r e f}=\sqrt{u_{1, F S}^{2}+u_{2, F S}^{2}}$.

The discrepancy in the pressure field captured on the two grids with $256 \times 24$ and 516x49 cells is negligible, indicating that even the coarser grid is sufficiently refined.

This conclusion is further supported by the airfoil surface static pressure and velocity distribution, presented as a function of airfoil chord in Fig. 7. The pressure coefficient in Fig. 7 (a) shows close agreement between the results on the two grids and the only notable discrepancy occurs in terms of the pressure minimum at $10 \% C_{a x}$ which is by $2.4 \%$ more pronounced on the fine grid.

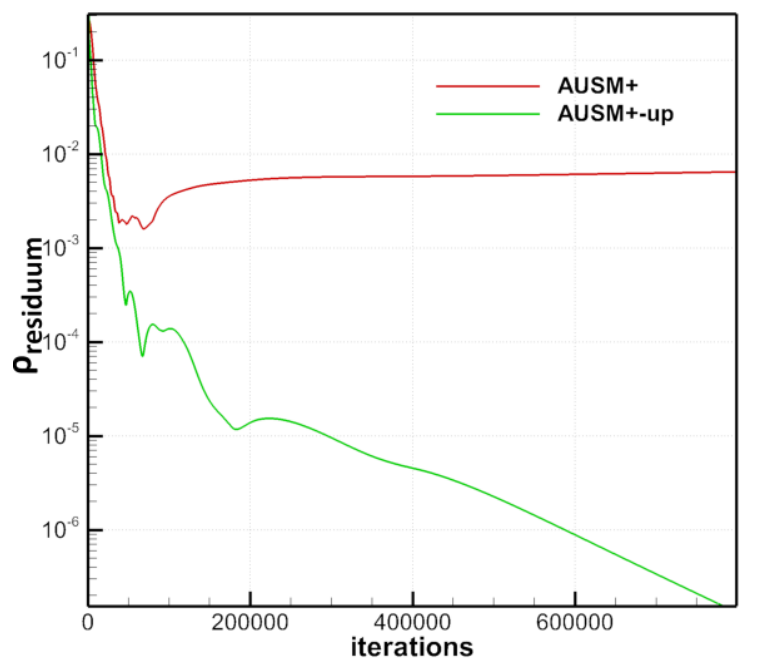

Fig. 5: Comparison of density residuals for AUSM+ and AUSM+-up schemes for $u_{1, F S}=$ $30 \mathrm{~m} / \mathrm{s}$

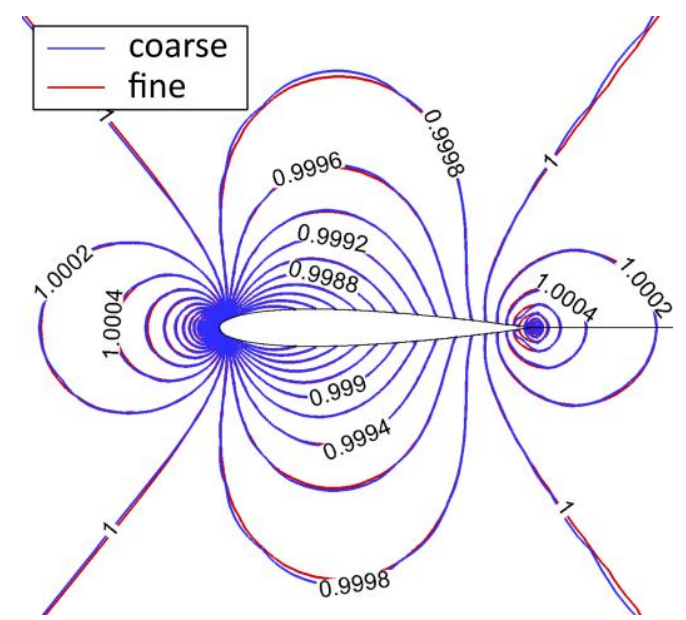

Fig. 6: Isolines of nondimensional pressure $p / p_{F S}$ on a coarse and fine grid

Validation is provided by the experimental data of Benetka [31] which agree remarkably closely with CFD everywhere apart from the pressure minimum between $10 \%$ and $30 \%$ of $C_{a x}$. This underprediction of the pressure drop is not exclusive to the numerical model employed in this work and it is reported also in works of other authors using both inviscid [24] and viscous [7] flow solvers. A close match within $1.3 \%$ between numerical and experimental results [32] is found in terms of the non-dimensional squared velocity $Q^{2}=$ $\left(u_{1}^{2}+u_{2}^{2}\right) / u_{r e f}^{2}$, plotted in the Fig. 7 (b). 


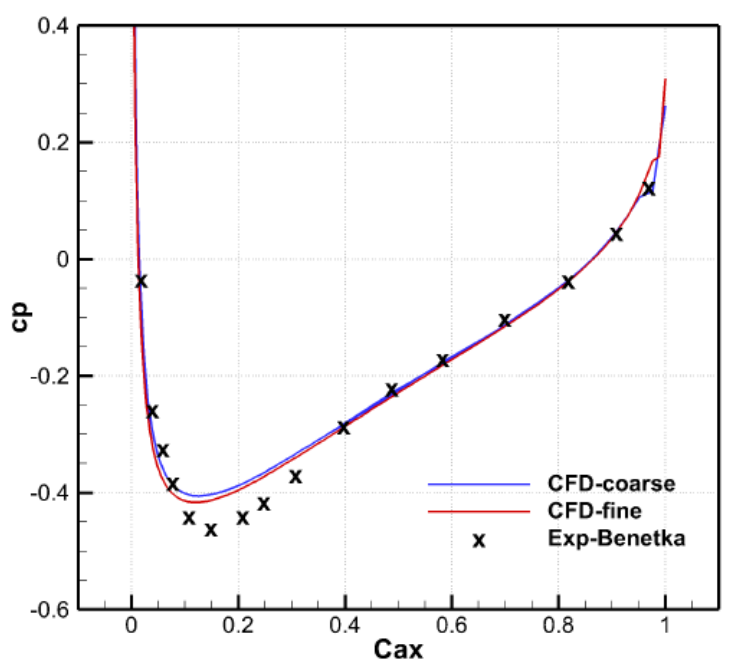

(a) Pressure coefficient

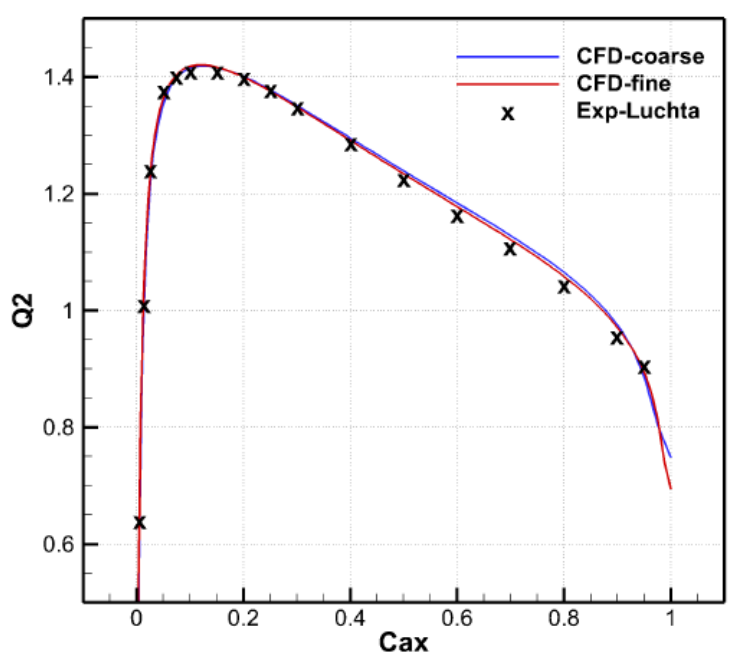

(b) Non-dimensional velocity squared

Fig. 7: Distribution of airfoil pressure coefficient $c_{p}$ and non-dimensional velocity squared $Q^{2}$ on a coarse and fine grid, compared with experimental data of Luchta [32] and Benetka [31]

\subsection{Prescribed Oscillation of Airfoil}

This chapter presents the unsteady flow solution for a vibrating airfoil with prescribed harmonic oscillations around elastic axis. The vertical position of the elastic axis is fixed to $h=0 \mathrm{~m}$ and the rotation angle $\phi$ is defined as

$$
\phi=\phi^{m a g}(2 \pi f t),
$$

with the pitching magnitude $\phi^{m a g}=3$ and frequency $f=30 \mathrm{~Hz}$.

The airfoil chord length is $\mathrm{c}=0: 1322 \mathrm{~m}$ and the position of elastic axis is $\xi_{E A}=0: 25 c$ (Fig. 2). The inlet boundary conditions are defined by the free-stream flow quantities $\rho_{F S}=1: 225$ $\mathrm{kg} / \mathrm{m}^{3}, u_{F S}=[136 ; 0]^{\mathrm{T}} \mathrm{m} / \mathrm{s}, p_{F S} \mathrm{pFS}=101325 \mathrm{~Pa}$.

The unsteady evolution of pressure coefficient $c_{p}$ is for each point on the airfoil surface approximated as

$$
c_{p}(t) \approx c_{p}^{\text {mean }}+c_{p}^{\text {mag }} \cdot \sin \left(2 \pi f t+c_{p}^{\phi}\right)
$$

where $f$ is the prescribed frequency of airfoil vibration, $c_{p}^{\text {mean }}$ is the time-averaged value of $c_{p}$, and the magnitude of oscillations $c_{p}^{\text {mag }}$ and the phase-shift $c_{p}^{\phi}$ are obtained by the leastsquares method.

The latter three quantities are plotted in Fig. 8 together with experimental results of Benetka [33] and Triebstein [34].

The time-averaged pressure coefficient shown in Fig. 8 (a) matches well with experimental data, although the minimum at $15 \% C_{a x}$ is less pronounced. Similar discrepancy between numerical and experimental data was already discussed for the steady solution in Section 4.1. The magnitude of $c_{p}$ oscillations plotted in Fig. 8 (b) is scaled to the pitching magnitude of 1 radian, i.e. multiplied by $180 / \pi / \phi^{m a g}$. The numerical predictions capture the trend of $c_{p}^{m a g}$ in agreement with the experimental results, although its magnitude is under predicted by up to $50 \%$ in the first half of $\mathrm{C}_{\mathrm{ax}}$. 


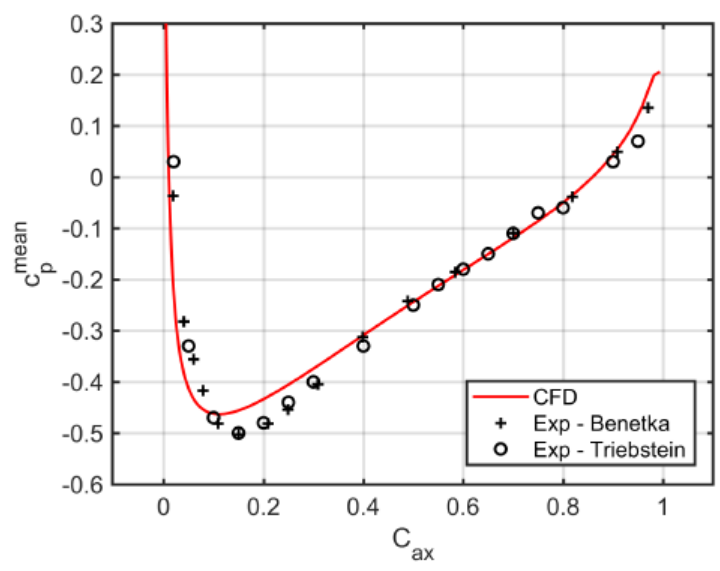

(a) Mean value

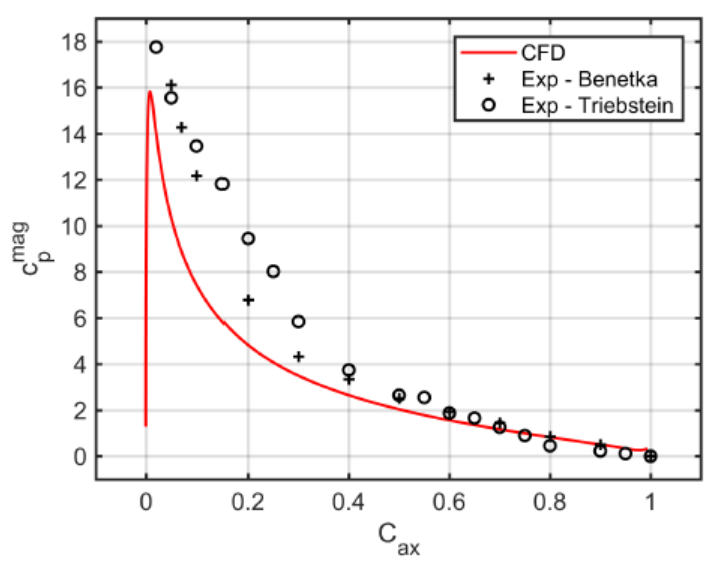

(b) Magnitude

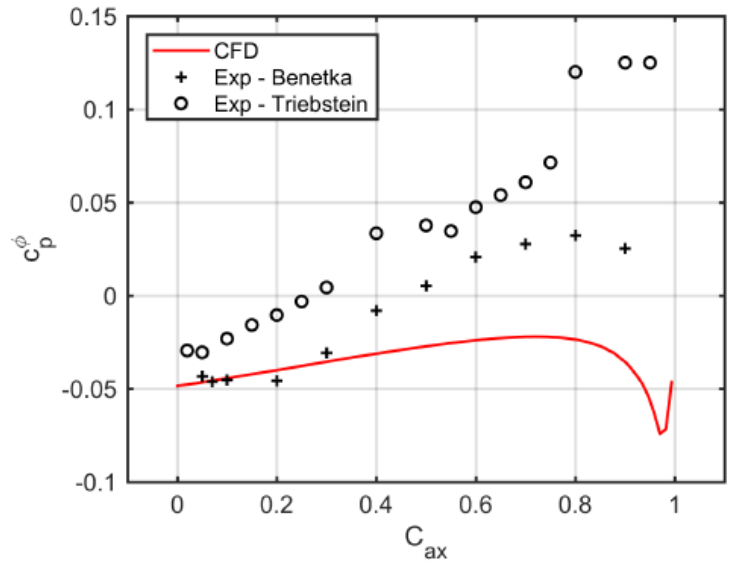

(c) Phase shift

Fig. 8: Mean value, magnitude and phase shift of $c_{p}$ during forced rotation. Comparison of CFD with experiments of Benetka [33] and Triebstein [34]

Both experimental and numerical data show that the phase-shift of $c_{p}$ is negative near the airfoil leading edge and increases towards the airfoil trailing edge. However, while both sets measurements indicate that the phase-shift reaches positive values in the aft part of chord, the numerical prediction remains negative along the full chord length. The discrepancies can be explained by the lack of viscous flow modelling and by the difference in the size of the experimental test section and of the computational domain. While the experimental channel extends only 2.3 chord lengths up and down from the airfoil in vertical direction, the corresponding dimension of the computational domain is 10 chord lengths.

\subsection{Airfoil Motion with Two Degrees of Freedom}

The flow induced vibrations of an airfoil with two degrees of freedom are described in this chapter. We consider an airfoil section extruded by $l=0.05 \mathrm{~m}$, with a weight $m=0.086622$ $\mathrm{kg}$, a static moment to elastic axis $S_{\phi}=-0.000779673 \mathrm{~kg} \mathrm{~m}$, a moment of inertia to elastic axis $I_{\phi}=0.000487291 \mathrm{~kg} \mathrm{~m}^{2}$, a chord length $\mathrm{c}=0.3 \mathrm{~m}$, a stiffness of support $k_{h h}=105.109$ $\mathrm{N} / \mathrm{m}$ in vertical displacement and $k_{\phi \phi}=3.695582 \mathrm{Nm} / \mathrm{rad}$ in rotation and the respective damping $b_{h} h=\epsilon k_{h h}, b_{\phi \phi}=\epsilon k_{\phi \phi}$, with $\epsilon=10^{-3}$. The positions of the elastic axis and center of gravity are $\xi_{E A}=0.4 \mathrm{c}$ and $\xi_{C G}=0.37 \mathrm{c}$ respectively, measured from the airfoil LE (Fig. 2). The remaining inlet conditions are defined by the free-stream quantities $p_{F S}=101325 \mathrm{~Pa}$ and $\rho_{F S}=1.225 \mathrm{~kg} / \mathrm{m}^{3}$. The horizontal component of the freestream velocity $u_{1, F S}$ is varied, while 
the vertical component $u_{2, F S}=0 \mathrm{~m} / \mathrm{s}$. The initial condition is obtained by running a computation with the airfoil in a fixed position until the solution converges to a steady-state.

The airfoil motion is described either by the non-linear (Eq. 9) or by the linearized (Eq. 10) equations of motion. Figure 9 compares the solutions obtained using these two definitions of airfoil movement for a freestream velocity $u_{1, F S}=43 \mathrm{~m} / \mathrm{s}$ and an initial airfoil displacement $\mathrm{h}_{0}=0: 05 \mathrm{~m}$ and pitching angle $\phi_{0}=6^{\circ}$. The temporal evolutions of the vertical displacement and pitching angle are plotted in Figs. 9 (a) and 9 (b) respectively. The linearization of the equations was performed under the assumption that the magnitude of the pitching angle $\phi$ is small and the evolutions of both quantities show that the solution is consistent with the original non-linear equations for $\phi<13^{\circ}$. However, as the equations are solved numerically in either case, it is possible to use the non-linear equations without any computational penalty. The integration in time is performed using either the explicit Euler or the RK4 scheme (Eqs. 24 and 27). The figures show only the results of the latter one, as the solution obtained by the Euler scheme matches so closely that it would not be discernible within the figure resolution. This results from the small time step of the order $10^{-7} \mathrm{~s}$, necessary for the stability of the explicit temporal integration schemes.

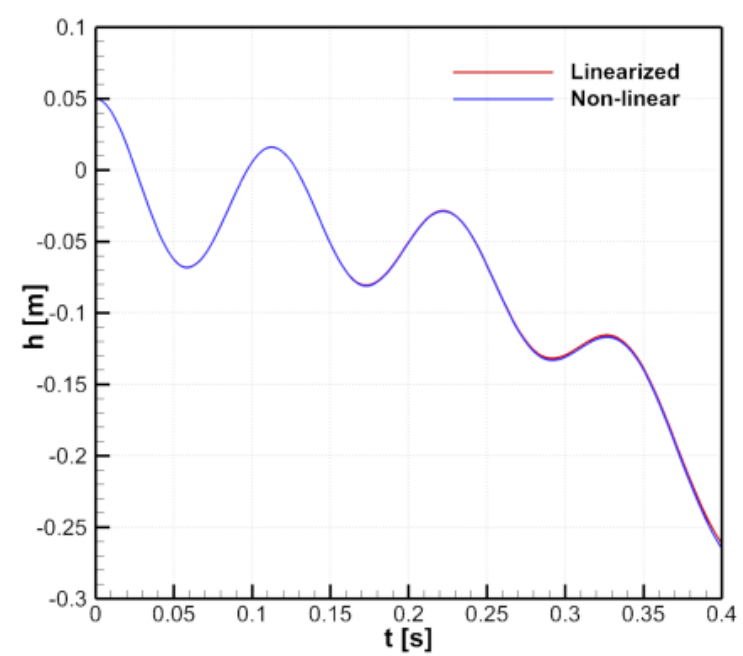

(a) Displacement

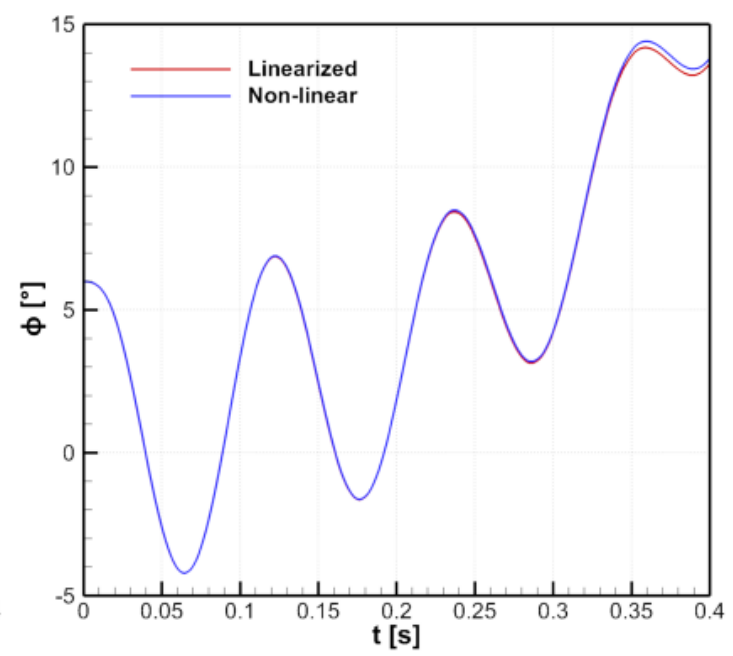

(b) Rotation angle

Fig. 9: Vertical displacement and rotation angle of flow-induced airfoil vibrations with $u_{1, F S}=43 \mathrm{~m} / \mathrm{s}$ using linearized and non-linear equations of airfoil motion

The dynamic behaviour of the system for different free-stream velocities ranging from $u_{F S}=30 \mathrm{~m} / \mathrm{s}$ to $u_{F S}=45 \mathrm{~m} / \mathrm{s}$ is plotted in Fig. 10 by means of the airfoil displacement $h$ (a) and pitching angle $\phi$ (b). The initial airfoil position is $\mathrm{h}_{0}=0.05$ and $\phi_{0}=6^{\circ}$ in all cases, the airfoil motion is described by the non-linear equations and the integration in time is performed by the RK4 method. The two cases with low freestream velocities, 30 and $35 \mathrm{~m} / \mathrm{s}$, exhibit a stable behaviour with both the airfoil vertical displacement $h$ and the pitching angle $\phi$ converging to zero values. An increase of freestream velocity to $40 \mathrm{~m} / \mathrm{s}$ results into an unstable behavior with both parameters diverging, although the airfoil oscillations are damped and flutter does not occur. This is in agreement with the results from NASTRAN cited in Honzátko's work [24], predicting a torsional divergence to occur at $u_{F S}=37.7 \mathrm{~m} / \mathrm{s}$ and flutter at $u_{F S}=42.4 \mathrm{~m} / \mathrm{s}$. According to this prediction, the last two plotted cases with freestream velocities of 43 and $45 \mathrm{~m} / \mathrm{s}$ should be above the flutter boundary. The plots show that the damping of oscillations becomes substantially weaker with increasing freestream velocity, however, due to the presence of the torsional divergence it is not possible to safely conclude whether flutter actually occurs. 


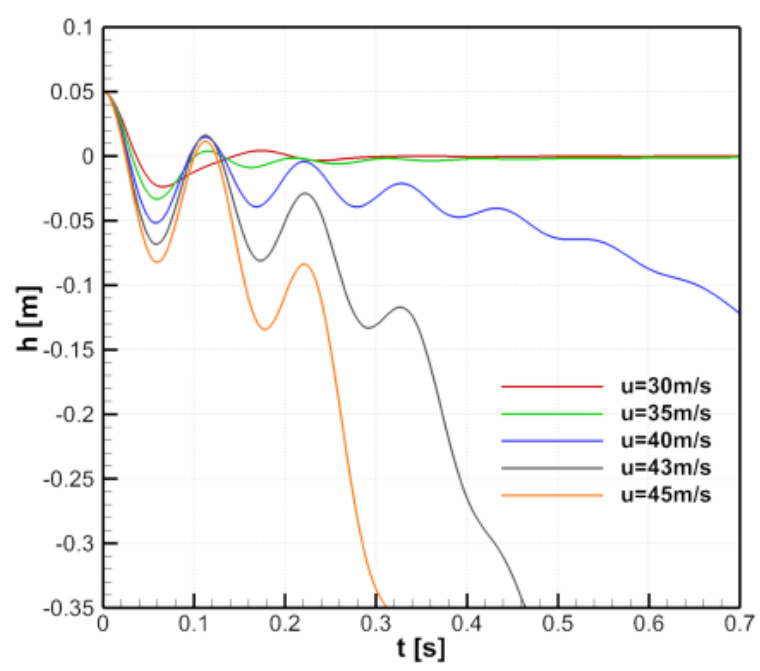

(a) Displacement

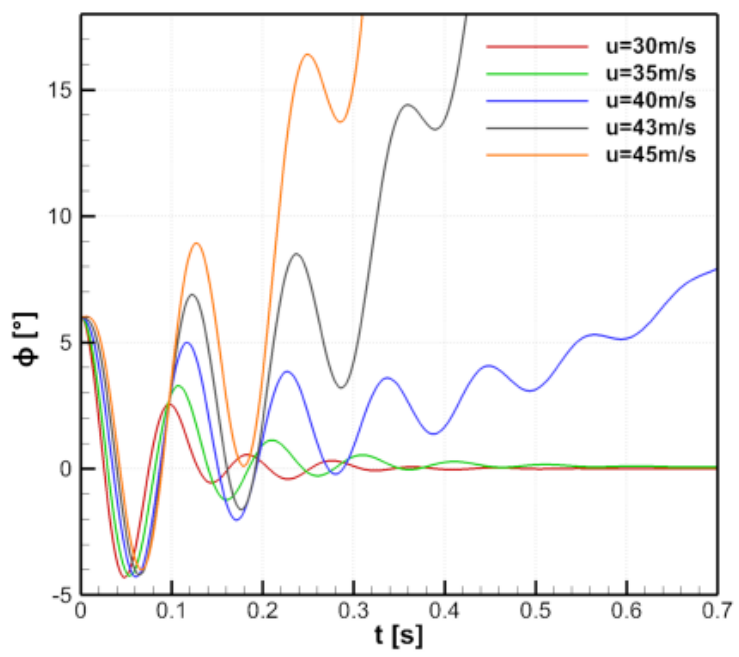

(b) Rotation angle

Fig. 10: Vertical displacement and rotation angle of flow-induced airfoil vibrations for varying $u_{1, F S}$

\section{Conclusions}

This paper presents results of a fluid-structure interaction model applied to the solution of flow-induced vibrations of a NACA 0012 airfoil on elastic support with two degrees of freedom. The inviscid flow model is based on the Euler equations and solved numerically by the FVM in ALE formulation. The strong two-way coupling between structure and fluid is realized via the aerodynamic loads transmitted to the structure and via the fluid-domain deformation due to the airfoil movement. The model was successfully validated by experimental data on a steady-state solution and on a test-case with forced harmonic vibrations of the airfoil. The results showed that using the $\mathrm{AUSM}^{+}$scheme for low-speed flow regimes leads to a presence of spurious pressure oscillations which are removed by the modified $\mathrm{AUSM}^{+}$-up scheme. The predictions of the fluid-structure interaction model were in agreement with the results of other authors, showing a stable behaviour of the system for low incoming flow velocities and a torsional divergence together with a weaker damping of oscillations for higher flow velocities.

\section{Acknowledgment}

Authors gratefully acknowledge support from the ESIF, EU Operational Programme Research, Development and Education, and from the Center of Advanced Aerospace Technology (CZ.02.1.01/0.0/0.0/-16 019/0000826), Faculty of Mechanical Engineering, Czech Technical University in Prague, and from the Grant Agency of CTU in Prague, grant No. SGS16/206/OHK2/3T/12.

\section{Nomenclature}

a speed of sound

ALE Arbitrary Lagrangian-Eulerian

$b_{\phi \phi} \quad$ damping in rotation

$b_{h h} \quad$ damping in vertical displacement

$c \quad$ airfoil chord length

$C_{a x}$ axial chord coordinate

$c_{p} \quad$ pressure coefficient 
CFD Computational Fluid Dynamics

CG center of gravity

CSM Computational Structural Mechanics

$d \quad$ distance

$e \quad$ internal energy

$e_{t} \quad$ total energy

EA elastic axis

F flux vector

$f \quad$ frequency of airfoil oscillations

$F_{y} \quad$ lifting force

FEM Finite Elements Method

FVM Finite Volumes Method

GCL Geometric Conservation Law

$h \quad$ vertical displacement of airfoil

$I_{\phi} \quad$ airfoil moment of inertia to EA

$k_{\phi \phi} \quad$ stiffness in rotation

$k_{h h} \quad$ stiffness in vertical displacement

$l \quad$ airfoil depth

LE airfoil leading edge

$m$ mass of airfoil

$\dot{m}$ mass-flow

$M \quad$ pitching moment

$n$ normal

NLH Non-Linear Harmonics

$p \quad$ static pressure

$Q \quad$ non-dimensionalized velocity

$\mathbf{R} \quad$ vector of residuals

$s \quad$ ALE velocity

$S_{\phi} \quad$ airfoil static moment to EA

$t$ time

$\boldsymbol{u} \quad$ velocity

W vector of characteristic variables

\section{Greek symbols}

$\gamma \quad$ Poisson constant

$\Omega \quad$ computational domain

$\Gamma \quad$ domain boundary

$\rho$ density

$\xi \quad$ coordinate along airfoil chord from LE

Sub- and Superscripts

0 initial

$1 / 2$ evaluated on the interface

FS free-stream

I inlet

$L / R \quad$ evaluated in one of the interface-adjacent cells

mag magnitude

mean time-averaged

o outlet 


$\begin{array}{cl}\text { r } & \text { relative } \\ \text { ref } & \text { reference } \\ { }_{w} & \text { wall } \\ \phi & \text { phase-shift }\end{array}$

\section{Literature}

[1] COLLAR, A. R.: The Expanding Domain of Aeroelasticity. The Aeronautical Journal. 1946, Vol. 50, Issue 428, pp. 613-636. DOI: 10.1017/S0368393100120358

[2] WICK, T.: Coupling of fully Eulerian and arbitrary Lagrangian-Eulerian methods for fluid-structure interaction computations. Computational Mechanics. 2013, Vol. 52, Issue 5, pp. 1113-1124. DOI: 10.1007/s00466-013-0866-3

[3] RZĄDKOWSKI, R.; GNESIN, V.: 3-D inviscid self-excited vibrations of a blade row in the last stage turbine. Journal of Fluids and Structures. 2007, Vol. 23, Issue 6, pp. 858-873. DOI: 10.1016/j.jfluidstructs.2006.12.003

[4] PETRIE-REPAR, P.; MAKHNOV, V.; SHABROV, N.; SMIRNOV, E.; GALAEV, S.; ELISEEV, K.: Advanced Flutter Analysis of a Long Shrouded Steam Turbine Blade. In: ASME Turbo Expo 2014: Turbine Technical Conference and Exposition. 2014, Paper No. GT2014-26874. ISBN 978-0-7918-4577-6. DOI: 10.1115/GT2014-26874

[5] SLONE, A. K.; PERICLEOUS, K.; BAILEY, C.; CROSS, M.; BENNETT, C.: A finite volume unstructured mesh approach to dynamic fluid-structure interaction: an assessment of the challenge of predicting the onset of flutter. Applied Mathematical Modelling. 2004, Vol. 28, Issue 2, pp. 211-239. DOI: 10.1016/S0307-904X(03)00142-2

[6] KAMAKOTI, R.; SHYY, W.: Fluid-structure interaction for aeroelastic applications. Progress in Aerospace Sciences. 2004, Vol. 40, Issue 8, pp. 535-558. DOI: $10.1016 /$ j.paerosci.2005.01.001

[7] SVÁČEK, P.; FEISTAUER, M.; HORÁČEK, J.: Numerical simulation of flow induced airfoil vibrations with large amplitudes. Journal of Fluids and Structures. 2007, Vol. 23, Issue 3, pp. 391-411. DOI: 10.1016/j.jfluidstructs.2006.10.005

[8] CORRAL, R.; JAVIER, C.: Development of an Edge-Based Harmonic Balance Method for Turbomachinery Flows. In: ASME 2011 Turbo Expo: Turbine Technical Conference and Exposition. 2011, Paper No. GT2011-45170. ISBN 978-0-7918-5467-9. DOI: $\underline{10.1115 / G T 2011-45170}$

[9] GNESIN, V. I.; KOLODYAZHNAYA, L. V.; RZADKOWSKI, R.: A numerical modelling of stator-rotor interaction in a turbine stage with oscillating blades. Journal of Fluids and Structures. 2004, Vol. 19, Issue 8, pp. 1141-1153. DOI: $10.1016 /$ j.jfluidstructs.2004.07.001

[10] MASSEREY, P.-A.; McBEAN, I.; LORINI, H. Analysis and improvement of vibrational behaviour on the ND37 A last stage blade. VGB Powertech Journal. 2012, Vol. 92, pp. 42-48.

[11] THEODORSEN, T.: Report No. 496: General Theory of Aerodynamic Instability and the Mechanism of Flutter. 1935. Technical Report. NASA Technical Documents.

[12] PERRY, B.: Re-Computation of Numerical Results Contained in NACA Report No. 496. 2015. Technical Report. NASA Langley Research Center; Hampton, Virginia, United States. 
[13] DOI, H.; ALONSO, J. J.: Fluid/Structure Coupled Aeroelastic Computations for Transonic Flows in Turbomachinery. In: ASME Turbo Expo 2002: Power for Land, Sea, and Air. 2002, Paper No. GT2002-30313. ISBN 0-7918-3609-6. eISBN 0-7918-3601-0. DOI: $10.1115 / \mathrm{GT} 2002-30313$

[14] NING, W.; HE, L.: Computation of Unsteady Flows Around Oscillating Blades Using Linear and Nonlinear Harmonic Euler Methods. Journal of Turbomachinery. 1998, Vol. 120, Issue 3, pp. 508-514. DOI: 10.1115/1.2841747

[15] SANCHES, R. A. K.; CODA, H. B.: On fluid-shell coupling using an arbitrary Lagrangian-Eulerian fluid solver coupled to a positional Lagrangian shell solver. Applied Mathematical Modelling. 2014, Vol. 38, Issue 14, pp. 3401-3418. DOI: $10.1016 /$ j.apm.2013.11.025

[16] DONEA, J.; GIULIANI, S.; HALLEUX, J. P.: An arbitrary lagrangian-eulerian finite element method for transient dynamic fluid-structure interactions. Computer Methods in Applied Mechanics and Engineering. 1982, Vol. 33, Issues 1-3, pp. 689-723. DOI: $\underline{10.1016 / 0045-7825(82) 90128-1}$

[17] BOFFI, D.; GASTALDI, L.: Stability and geometric conservation laws for ALE formulations. Computer Methods in Applied Mechanics and Engineering. 2004, Vol. 193, Issues 42-44, pp. 4717-4739. DOI: 10.1016/j.cma.2004.02.020

[18] SAKSONO, P. H.; DETTMER, W. G.; PERIĆ, D.: An adaptive remeshing strategy for flows with moving boundaries and fluid-structure interaction. International Journal for Numerical Methods in Engineering. 2007, Vol.71, Issue 9, pp. 1009-1050. DOI: $10.1002 / \mathrm{nme} .1971$

[19] MAY, M.; MAUFFREY, Y.; SICOT, F.: Numerical flutter analysis of turbomachinery bladings based on time-linearized, time-spectral and time-accurate simulations. In: Proceedings of IFASD 2011 - 15th International Forum on Aeroelasticity and Structural Dynamics. 2011, Paper No. IFASD-2011-080.

[20] HÖHN, W.: Numerical Investigation of Blade Flutter at or Near Stall in Axial Turbomachines. In: ASME Turbo Expo 2001: Power for Land, Sea, and Air. 2001, Paper No. 2001-GT-0265. ISBN 978-0-7918-7853-8. DOI: $10.1115 / 2001-G T-0265$

[21] STOREY, P.: Holographic Vibration Measurement of a Rotating Fluttering Fan. In: Proceedings of AIAA/SAE/ASME $18^{\text {th }}$ Joint Propulsion Conference. 1982. DOI: $\underline{10.2514 / 6.1982-1271}$

[22] SLONE, A. K.; BAILEY, C.; CROSS, M.: Dynamic Solid Mechanics Using Finite Volume Methods. Applied Mathematical Modelling. 2003, Vol. 27, Issue 2, pp. 69-87. DOI: $10.1016 / \mathrm{S} 0307-904 \mathrm{X}(02) 00060-4$

[23] SLONE, A. K.; PERICLEOUS, K.; BAILEY, C.; CROSS, M.: Dynamic fluid-structure interaction using finite volume unstructured mesh procedures. Computers \& Structures. 2002, Vol. 80, Issues 5-6, pp. 371-390. DOI: 10.1016/S0045-7949(01)00177-8

[24] HONZÁTKO, R.: Numerical Simulations of Incompressible Flows with Dynamical and Aeroelastic Effects. PhD thesis. Czech Technical University in Prague, 2007.

[25] LIOU, M.-S.; STEFFEN Jr., Ch. J.: A New Flux Splitting Scheme. Journal of Computational Physics. 1993, Vol. 107, Issue 1, pp. 23-39. DOI: $10.1006 /$ jcph.1993.1122 
[26] LIOU, M.-S.: A sequel to AUSM, Part II: AUSM ${ }^{+}$-up for all speeds. Journal of Computational Physics. 2006, Vol. 214, Issue 1, pp. 137-170. DOI: $\underline{10.1016 / j . j c p .2005 .09 .020}$

[27] SMITH, R. W.: AUSM(ALE): A Geometrically Conservative Arbitrary LagrangianEulerian Flux Splitting Scheme. Journal of Computational Physics. 1999, Vol. 150, Issue 1, pp. 268-286. DOI: 10.1006/jcph.1998.6180

[28] LIOU, M.-S.: A Sequel to AUSM: AUSM+'. Journal of Computational Physics. 1996, Vol. 129, Issue 2, pp. 364-382. DOI: $10.1006 /$ jcph.1996.0256

[29] DARRACQ, D.; CHAMPAGNEUX, S.; CORJON, A.: Computation of Unsteady Turbulent Airfoil Flows with an Aeroelastic AUSM+ Implicit Solver. In: Proceedings of 16th AIAA Applied Aerodynamics Conference. 1998. DOI: 10.2514/6.1998-2411

[30] HIRSCH, Ch.: Numerical Computation of Internal and External Flows. The Fundamentals of Computational Fluid Dynamics. Elsevier, 2007. ISBN 978-0-75066594-0. DOI: 10.1016/B978-0-7506-6594-0.X5037-1

[31] BENETKA, J.: Měrení kmitajícího profilu v různě vysokých měricích prostorech. 1981. Technical Report Z-2610/81. Aeronautical Research and Test Institute, Prague, Letňany.

[32] LUCHTA, J.: Sbornik charakteristik profilů křidel. 1955. Technical Report 1669/55. VTA AZ, Brno.

[33] BENETKA, J.; KLADRUBSKÝ, J.; VALENTA, R.: Measurement of NACA 0012 profile in a slotted measurement section. 1998. Technical Report R-2909/98. Aeronautical Research and Test Institute, Prague, Letňany.

[34] TRIEBSTEIN, H.: Steady and unsteady transonic pressure distributions on NACA 0012. Journal of Aircraft. 1986, Vol. 23, Issue 3, pp. 213-219. DOI: $10.2514 / 3.45291$ 


\section{NUMERICKÁ SIMULACE AEROELASTICKÝCH ÚČINKU゚ PRO PROFIL KŘÍDLA S DRUHÝM STUPNĚM VOLNOSTI}

Zvyšování výkonu parních turbín vede $\mathrm{k}$ návrhu nízkotlakých stupňů o velkém průměru, vyznačujících se dlouhými a tenkými lopatkami. Interakce pevných těles s prouděním může způsobit vibrace, které mají za následek sníženou životnost stroje kvůli únavě materiálu. Tato práce představuje matematický model interakce pevného tělesa $\mathrm{s}$ tekutinou, navržený za účelem zkoumání vibrací způsobených prouděním. Model je zde aplikován na zjednodušený testovací př́ípad osamoceného profilu leteckého kř́́lla. Model proudění je založen na Eulerových rovnicích $\mathrm{v}$ Arbitrary Lagrange-Euler formulaci, diskretizovaných metodou konečných objemů. Jeho validace je provedena prostřednictvím srovnání s experimentálními daty a s numerickými výsledky jiných autorů.

\section{NUMERISCHE SIMULATION AEROELASTISCHER WIRKUNGEN FÜR DAS PROFIL DER TRAGFLÄCHE MIT DEM ZWEITEN FREIHEITSGRAD}

Die Erhöhung der Leistung von Dampfturbinen führt zum Entwurf von Niedrigdruckgraden mit einem großen Durchschnitt. Diese Grade zeichnen sich durch lange und dünne Schaufeln aus. Die Interaktion der Festkörper mit der Strömung kann Vibrationen erzeugen, welche eine kürzere Lebensdauer der Maschine auf Grund von Materialermüdung zur Folge haben. Diese Arbeit stellt ein mathematisches Modell der Interaktion des festen Körpers mit Flüssigkeit vor, welches zum Zweck der Erforschung von durch Strömung verursachten Vibrationen entworfen worden ist. Das Strömungsmodell basiert auf den Eulergleichungen in der Arbitrary Lagrange-Euler-Formulierung, welche durch die Methode der endlichen Inhalte diskretisiert werden. Die Validierung des Strömungsmodells wird mittels Vergleich mit den experimentellen Daten und mit den numerischen Ergebnissen anderer Autoren durchgeführt.

\section{NUMERYCZNA SYMULACJA AEROELASTYCZNEGO ODDZIAŁYWANIA NA PROFIL SKRZYDEA Z DRUGIM STOPNIEM SWOBODY}

Zwiększanie mocy turbin parowych skutkuje projektowaniem stopni niskociśnieniowych o dużej średnicy, charakteryzujących się długimi i cienkimi łopatkami. Interakcja ciał stałych ze strumieniem powietrza (wiatrem) może wywołać drgania, które wpływają na skrócenie okresu wytrzymałości maszyny z powodu zmęczenia materiału. Niniejsze opracowanie przedstawia matematyczny model interakcji ciała stałego $\mathrm{z}$ płynem, opracowany w celu badania drgań spowodowanych przepływem powietrza. Model można zastosować do uproszczonego testowania samodzielnego profilu skrzydła samolotu. Model przepływu powietrza bazuje na równaniach Eulera w procedurze Arbritrary Lagrange-Euler (ALE), zdyskretyzowanych metodą objętości skończonych. Jego walidację przeprowadzono w drodze porównania z danymi doświadczalnymi i numerycznymi wynikami innych autorów. 